\title{
First record of an elephant fish (Chondrichthyes, Holocephali) in Ecuadorian waters during an ENSO event
}

\author{
Primer registro de un pez elefante (Chondrichthyes, Holocephali) \\ en aguas ecuatorianas durante un acontecimiento ENOS \\ Kelly Swing ${ }^{1}$ and Philippe Béarez ${ }^{2}$ \\ ${ }^{1}$ Universidad San Francisco de Quito, Colegio de Ciencias de la Vida, PO Box 17-12-841, Quito, Ecuador \\ ${ }^{2} U M R$ 5197, Département «Écologie et gestion de la biodiversité», Muséum national d'histoire naturelle, \\ 55 rue Buffon, 75231 Paris cedex 05, France \\ bearez@mnhn.fr
}

Resumen.- Un pez elefante se reporta por la primera vez del Ecuador continental. Un solo espécimen del pejegallo suramericano común, Callorhinchus callorynchus, fue recogido en Puerto López en 1998. Este registro corresponde a una extensión del rango de distribución hacia el norte de por lo menos 500 km. Su ocurrencia en Ecuador podría ser ligada al acontecimiento de La Niña 1998-2001.

Palabras clave: Peces, rango de extension, Océano Pacífico, Callorhinchus callorynchus, ENOS
Holocephali, the vertebrate subclass including the chimaeras, comprises three families, all marine (Nelson 1994). Two of these families, Chimaeridae (shortnose chimaeras, 27 species) and Rhinochimaeridae (longnose chimaeras, 8 species) have rather broad distributions but the Callorhinchidae (plownose chimaeras, 3 species) are only represented in the Southern Hemisphere, being reported primarily from temperate to subpolar latitudes. Holocephali are still poorly known and new species continue to be described (Didier 2002, Didier \& Séret 2002, Soto \& Vooren 2004). In South American waters, there is only one species of Callorhinchidae, Callorhinchus callorynchus (Linnaeus 1758), known from Brazil, Uruguay, Argentina, Chile, and Peru (Cousseau \& Perrotta 2000, Chirichigno \& Cornejo 2001). Its northernmost documented occurrence along the Pacific coast was Punta La Negra (6 $6^{\circ} 06^{\prime}$ S), Peru (Scripps Institution of Oceanography, catalog number SIO 58-423). Here we report for the first time the occurrence of Callorhinchus callorynchus at $1^{\circ} 33^{\prime} \mathrm{S}$ on the central Pacific coast of Ecuador, which represents a range extension of at least $500 \mathrm{~km}$ (Fig. 1).

The recent publication of a guide to the marine fishes of Ecuador (Jiménez-Prado \& Béarez 2004) accentuated the fact that this group had not been reported for Ecuadorian waters. Because data collection for that publication involved extensive visits to coastal

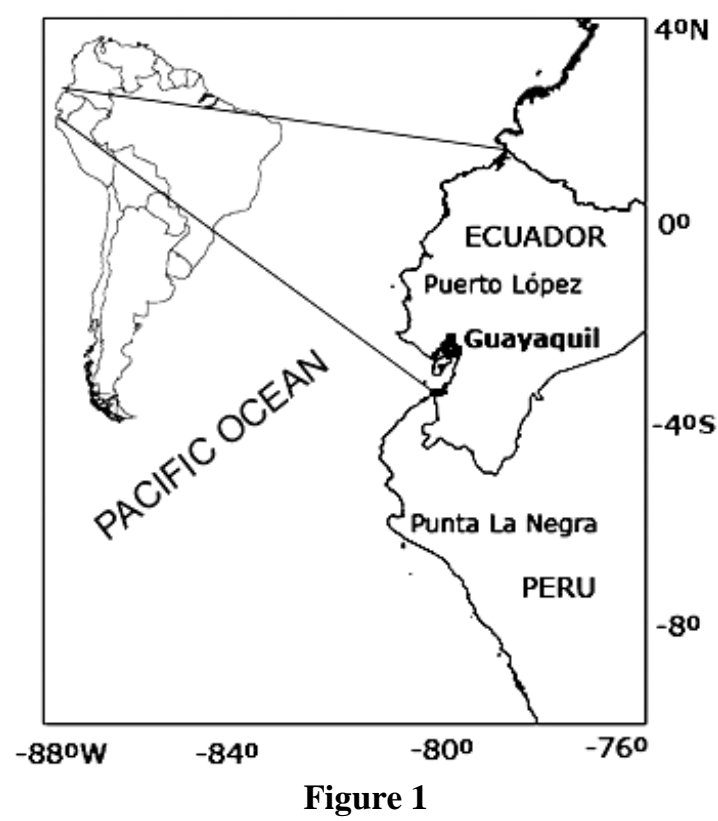

Map showing the locality of capture (Puerto López, Ecuador) and the previous northernmost point of known distribution (Punta La Negra, Peru) of Callorhinchus callorynchus

Mapa mostrando el lugar de la captura (Puerto López, Ecuador) y el punto más norteño de la distribución anteriormente conocida (Punta La Negra, Perú) de Callorhinchus callorynchus 
fish markets, it is concluded that elephant fishes are not captured through typical local fishing, and hence are not common residents. In confirmation, a total of several hundred hours of visits by the authors to Ecuadorian artisanal fish markets over a period of 15 years has also not yielded the observation of a single elephant fish. This fish is not known by local fishermen.

On 10 July 1998, Mr. Alfonso Pinoargotty, a local ecotourism business owner acquired a specimen of a "strange fish with an elephant snout" at the Puerto López fish market (Manabí Province) and brought it to the attention of KS (Fig. 2). This unique specimen (720 mm TL, $455 \mathrm{~mm}$ precaudal length) of Callorhinchus callorynchus, an adult male (clasper length $93 \mathrm{~mm}$ ), is presently housed at the Universidad San Francisco de Quito (collection number CKS 980710). Its coloration when fresh was silvery whitish but this turned to a dark ground color with a series of 7 large lateral black blotches once in alcohol. This species is easily recognized by the characteristic fleshy hooklike "plow nose", the expansive pectoral fins (170 mm length), the tall dorsal spine (127 mm length), the deep and robust head (135 mm head length) and the large eyes (20 mm cranio-caudal diameter). The characteristics of this specimen agree well with the description given by Evermann \& Radcliffe (1917) for a specimen caught at La Ventanilla, close to Lima, Peru. Hildebrand (1946) mentions that considerable variation does exist among specimens, especially with respect to dorsal fin position, dorsal spine length and pectoral fin length.

Elephant fishes are commonly caught off the central coast of Chile, but only occasionally off Peru, but it should be pointed out that there is little incentive for capture since low market acceptance exists in that region (PB pers. obs.). Nonetheless, it is believed that they become very rare north of $7^{\circ} \mathrm{S}$ (A. Vildoso pers. com. 2005). In more southerly regions, this species regularly appears in small scale fisheries, mainly caught by gill-netting. In Puerto López, long-lines and trammel or gill nets are the main fishing devices, used between depths of 50 and $200 \mathrm{~m}$. There is no deep-water trawling in the area, but shrimp trawling does occur in shallow water. Because both capture technique and depth for our specimen are undocumented, and because there is no evidence of being hooked, we must assume that it was taken in a gill net.

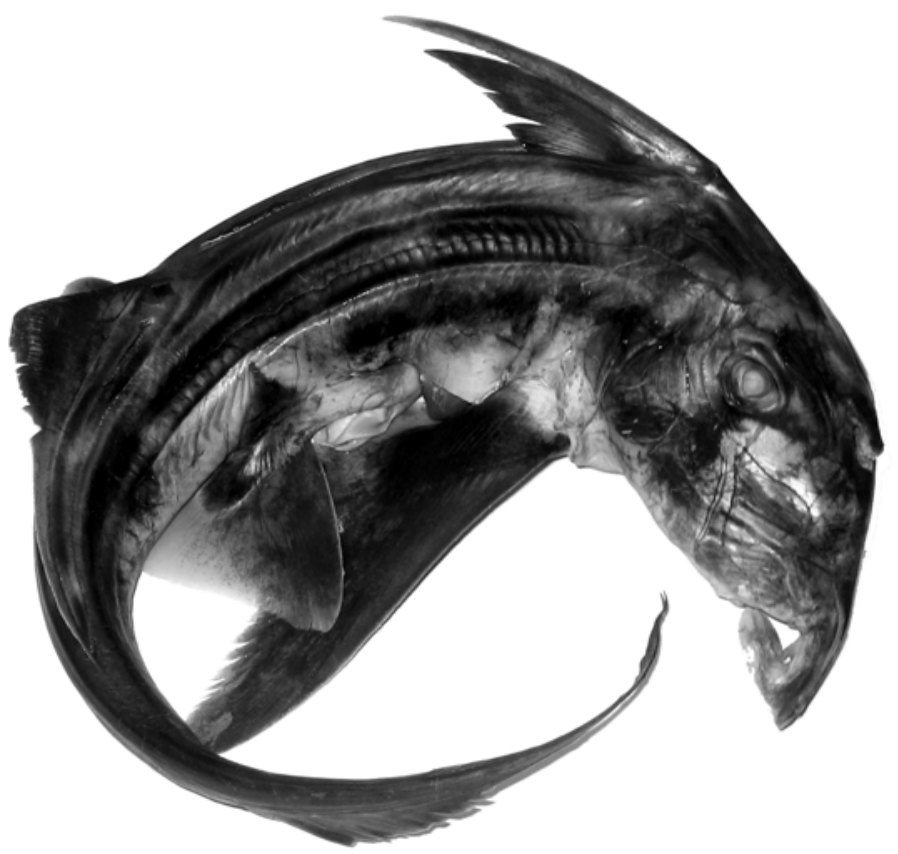

Figure 2

Callorhinchus callorynchus, 720 mm TL, Puerto López, Ecuador (Photo K. Swing)

Callorhinchus callorynchus, 720 mm LT, Puerto López, Ecuador (Foto K. Swing) 
Because the capture of this individual coincided with a strong El Niño event (1997-98), one would assume that climatic factors were responsible for its occurrence so unusually close to the equator. It is well known that many organisms undergo tremendous changes in distribution in conjunction with such events due to extensions or contractions of the conditions that define their typical habitats. As a cool-water species, however, the presence of this elephant fish in equatorial waters might seem difficult to explain. But, according to McPhaden (1999), the warm El Niño event of 1997-98 was followed almost immediately by a cold La Niña event which began in June 1998 and lasted until February 2001 (Béarez \& Jiménez-Prado 2003). This transition from El Niño to La Niña conditions characterized by the sudden strengthening of the northward flow of the Humboldt Current and the reestablishment of a more typical thermocline, undoubtedly produced a cool underlayer favorable to this benthic species. Chirichigno \& Cornejo (2001) mention that this elephant fish can be found between depths of 30 and $135 \mathrm{~m}$, but Evermann \& Radcliffe (1917) report that their specimen was taken in the surf, and PB has also observed specimens caught by beach seining in southern Peru. It has been previously observed (Béarez \& Jiménez-Prado 2003) that several cool water species, common in shallow Chilean or Peruvian waters are also found in Ecuador but at comparatively greater depths, generally between 50 and $100 \mathrm{~m}$. Therefore, it is plausible that this individual moved inshore from cooler deeper waters and thus became more available to artisanal fishermen during the La Niña event. Finally, it is difficult to conclude on the basis of a single individual whether the capture of this species in equatorial waters was due to a long-distance northward migration (500 km) or simply local movement from deeper to shallower waters (near the equatorial latitude where it was captured). In any case, its availability for capture by artisanal fishermen of the central Ecuadorian coast precisely at this time is an indication of changing conditions associated with El Niño events. Larval dispersal is discounted as the eggs of this species are encased and demersal.

\section{Literature cited}

Béarez $\mathbf{P}$ \& $\mathbf{P}$ Jiménez-Prado. 2003. New records of serranids (Perciformes) from the continental shelf of Ecuador with a key to the species, and comments on ENSO-associated fish dispersal. Cybium 27(2): 107-115.

Chirichigno N \& RM Cornejo. 2001. Catálogo comentado de los peces marinos del Perú. Publicación Especial del Instituto del Mar del Perú. Callao, 314 pp.

Cousseau MB \& RG Perrotta. 2000. Peces marinos de Argentina. Biología, distribución, pesca, 167 pp. Instituto Nacional de Investigación y Desarrollo Pesquero, Mar del Plata.

Didier DA. 2002. Two new species of chimaeroid fishes from the southwestern Pacific Ocean (Holocephali, Chimaeridae). Ichthyological Research 49(4): 299-306.

Didier DA \& B Séret. 2002. Chimaeroid fishes of New Caledonia with description of a new species of Hydrolagus (Chondrichthyes, Holocephali). Cybium 26(3): 225-233.

Evermann BW \& L Radcliffe. 1917. The fishes of the West coast of Peru and Titicaca basin. United States National Museum Bulletin 95: 1-166.

Hildebrand SF. 1946. A descriptive catalog of the shore fishes of Peru. United States National Museum Bulletin 189: 1-530.

Jiménez-Prado P \& P Béarez. 2004. Peces marinos del Ecuador continental / Marine fishes of continental Ecuador, T. 1, 130 pp.; T. 2, 401 pp. Sociedad para la Investigación y Monitoreo de la Biodiversidad Ecuatoriana/Nazca/Instituto Francés de Estudios Andinos, Quito.

McPhaden MJ. 1999. Genesis and evolution of the 1997-98 El Niño. Science 283: 950-954.

Nelson JS. 1994. Fishes of the world, 600 pp. John Wiley \& Sons, New York.

Soto JMR \& CM Vooren. 2004. Hydrolagus matallanasi sp. nov. (Holocephali, Chimaeridae) a new species of rabbitfish from southern Brazil. Zootaxa 687: 1-10. 